\title{
一様流作用下におけるPC桁の流出の限界値評価 に関する実験的検討
}

\author{
渡辺 健 ${ }^{1} \cdot$ 大野 $^{\text {又稔 }}{ }^{2}$ 織田 幸伸 3 \\ 1正会員（公財）鉄道総合技術研究所構造物技術研究部（干185-8540 東京都国分寺市光町2-8-38) \\ E-mail: watanabe.ken.08@rtri.or.jp \\ 2正会員 (公財)鉄道総合技術研究所構造物技術研究部（二185-8540 東京都国分寺市光町2-8-38） \\ E-mail:ono.yuto.47@rtri.or.jp \\ 3 大成建設(株) 技術センター土木技術研究所 \\ E-mail: od-ykn00@pub.taisei.co.jp
}

\begin{abstract}
本研究は，津波による桁流出に対する橋りょうの抵抗力を把握することを目的とする. 津波により準定 常状態の流れが作用する状況を対象に, 桁・橋脚・支承部形式の異なる鉄道コンクリート橋りょうの流出 について，縮小橋りょう模型を用いた流体作用実験を行った。 その結果，一様流による桁流出に対する抵 抗力は，断面形状および支承形式に依存することを明らかとし，また従来使用されている移動制限装置の 有効性を確認した。桁流出時に作用した流体力（水平方向 $F_{x}$, 鉛直方向 $F_{z}$, 回転方向 $M_{y 0}$ ） と, 支承の摩擦 力，ストッパーのせん断力により算出される抵抗力を比較すると，流体力の $\left(F_{x}, F_{z}, M_{y 0}\right)$ いずれかが抵 抗力を上回っており, 流出状況とも一致することが確認され, 桁の流出判定が可能であることが示された.
\end{abstract}

key words : tsunami, bridge, fluid force, pc girder, uniform flow, quasi-steady flow

\section{1. はじめに}

東日本大震災では，沿岸部の鉄道橋りょうが多数流失 し甚大な被害を受けた。また，近い将来に発生が懸念さ れている東海・東南海・南海地震によって，東海，近畿 および四国などの沿岸部の鉄道が大きな被害を受けるこ とが想定される.このような沿岸部に位置する構造物は, 旧基準で設計された構造物がほとんどであり，無筋コン クリート橋脚や，桁の移動に対する抵抗性の乏しい支承 を有する構造物が多い，近年，橋りょう流出に関する作 用，応答值，限界值について多くの研究が実施されてお り，著者らもこれまで橋りょう模型を用いた津波作用の 模型実験や数值解析を行い，様々な流体情報と桁の諸元 が桁の流体力に及ぼす影響について検討を行った ${ }^{1)}$.

これに対して本研究は，桁断面形状，橋脚高さ，支承 部形式の異なる縮小試験体を用いた水理実験により，津 波による桁流出に対する橋りょうの抵抗力の特性を把握 することを目的としている，これまで，橋りょう流出に 関する限界值を評価できるマクロ式として，支承の摩擦 や桁の重量に頼った支承まわりの回転力2) あるいは浮き 上がりに対する抵抗力 ${ }^{3)}$ に着目して整理された事例が報 告されている，様々な流体情報および橋りょう情報に対
する適用方法については検討の余地が残されているもの の，流れ方向，鉛直方向および橋軸回りの回転方向に対 する抵抗力に着目して，橋りょう流出に対する限界值を マクロ式に基づいて検討することは，一定の合意が得ら れていると言える.ここでは，既往の研究で対象となる ことが多い道路橋と比較して，スパンが同程度であって も桁高が大きい特徴を有する，鉄道橋りょうに焦点を絞 り, 準定常状態の流速が働く状況を対象に検討する. なお本研究では，橋りょう流出の限界状態として，支承 位置において桁と橋脚がかい離する状態を対象とし，橋 脚の破壊による流出は検討の対象としない.

\section{2. 実験概要}

\section{(1) 検討対象および実験水槽}

図-1 に縮小橋りょう模型を，図-2 に実験水路の断面 を示す．水路内には，3 径間（桁間 : $1 \mathrm{~mm}$ ）の橋りょう 模型を設置し, 中央径間を試験対象とした. なお両側の 径間は，中央径間に先行して流出することを防止するた めにワイヤーで固定した，模型縮尺を $1 / 40$ とし，実験 諸元はフルードの相似則にしたがって設定した. 対象と する現象の最小流速を $2.0 \mathrm{~m} / \mathrm{s}$ (実機) とすると, 水の動 


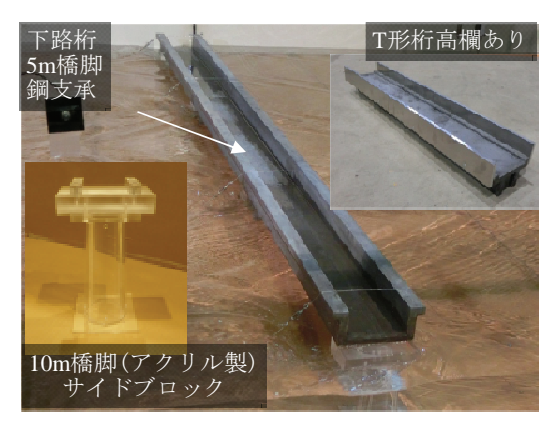

図-1＼cjkstart縮小橋りょう模型

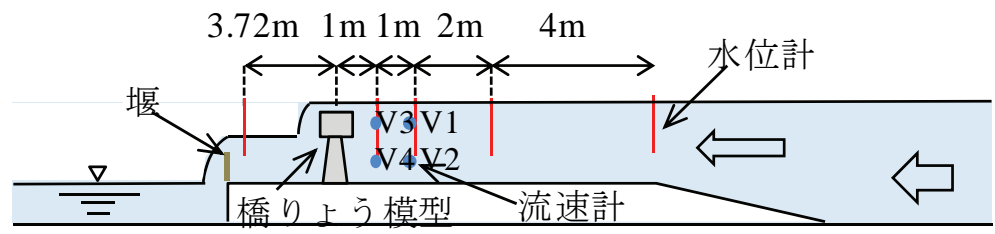

図-2 実験水路，模型配置および計測位置

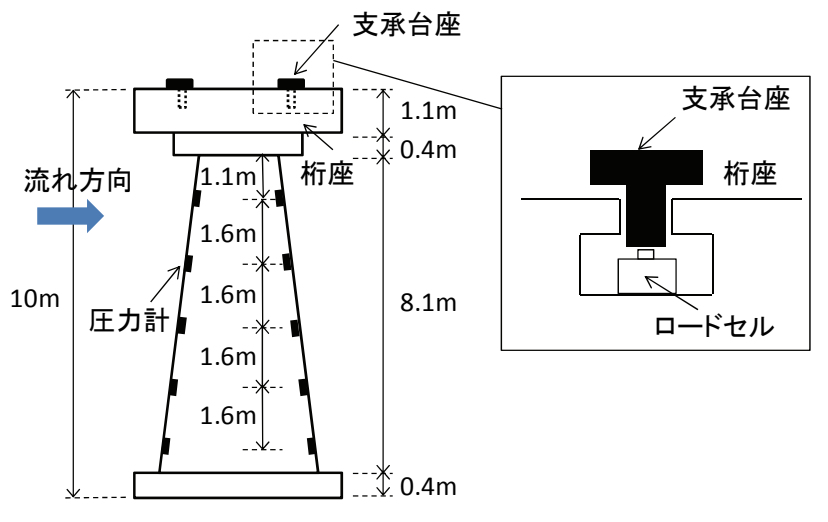

図-3 10m 橋脚試験体（実機換算寸法）

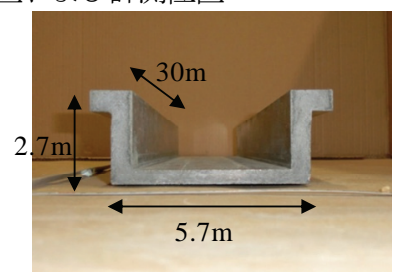

(a)下路椼(G1)



(b)T形桁高欄あり(G2)

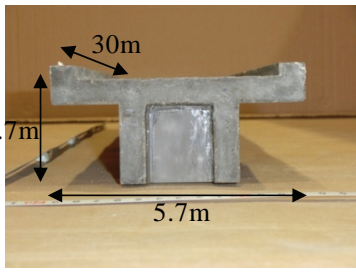

(c)T形析高欄なL(G3)

図-4 桁形式（実機換算寸法）

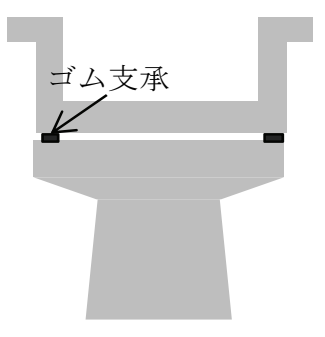

(a) $\mathrm{S} 1$

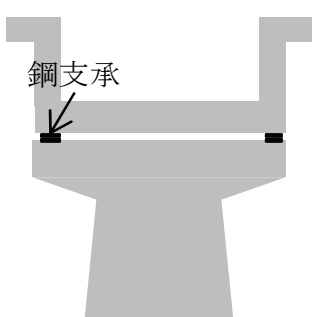

(b) $\mathrm{S} 2$

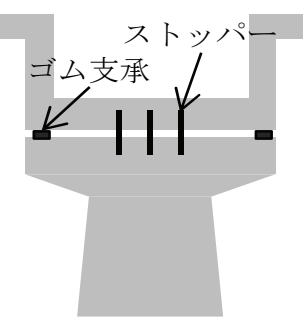

(c) S3

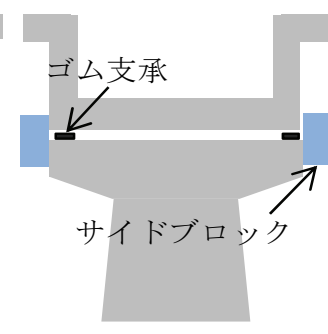

(d) S4

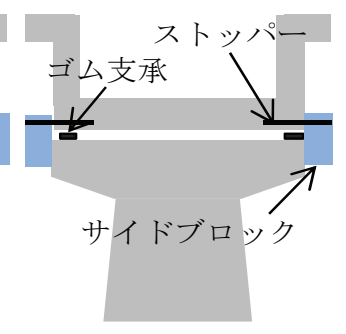

(e) S5

図-5 支承および落橋防止装置の形式

粘性係数 $v=1.14 \times 10^{-2} \mathrm{~cm}^{2} / \mathrm{s}\left(15^{\circ} \mathrm{C}\right)$, 最小橋林高さ $2.7 \mathrm{~m}$ から求められるレイノルズ数 $R_{e}$ は, 実機で $4.74 \times 10^{6}$, 縮 尺模型で $1.87 \times 10^{4}$ となり，模型においても十分に大きく, 乱流状態であり水の粘性の影響は無視できる程度に小さ いと考えられる.

橋脚の柱部は円錐台形状とした． 実験対象とする橋脚 高さすなわち桁下空頭は， $10 \mathrm{~m}$ と $5 \mathrm{~m}$ (実機換算寸法) の 2 種類とした．橋脚試験体は，アクリルにより制作し， 上下流側の側面に，圧力計を設置した (図-3参照).

図-4に，実験に使用した林模型の諸元を示す．断面 寸法・形状は，鉄道橋りょうに使用されている鉄道プレ ストレストコンクリート(PC)下路桁と PCT形枌を参考に したものであり，防音壁の有無を含めた 3 タイプ (G1, G2，G3）とした．林長は 30m（実機換算寸法）である. 桁模型は，実機スケールに換算した桁の総重量が，実物 と同程度となるように，超高強度䋊維補強コンクリート
4)（UFC）で製作した。ただし， PCT 桁の防音壁のみ, 薄板のためアルミ製とした.

図-5に，今回対象とした支承形式を示寸。実験対象と する支承部の形式は，ゴム製支承 S1（摩擦係数 0.5 , 長 さ $10 \mathrm{~mm} \times$ 幅 $10 \mathrm{~mm} \times$ 高さ $2 \mathrm{~mm}$ ), 鋼製支承 $\mathrm{S} 2$ （長さ $10 \mathrm{~mm} \times$ 幅 $10 \mathrm{~mm} \times$ 高さ $1 \mathrm{~mm}$ ），および地震動作用に対 する移動制限装置として供用されている鋼棒 (S3)または サイドブロック(S4)をゴム製支承と併設したもの，およ び S4 に鉛直方向の移動制限装置として鋼棒を配置した 形式 S5 の計 5 種類とした.

ゴム製支承は橋脚模型に接着し，また鋼製支承 S2 で は，2 枚のアルミ（摩擦係数 0.3）を用いており, それ ぞれ桁模型および橋脚模型の支承位置に接着した. S3 における鋼棒は直径 $2 \mathrm{~mm}$ の真鍮棒であり， $12.5 \mathrm{~mm}$ 間隔 で 3 本設置されている. 各鋼棒は橋脚模型側に固定し, 桁模型側には直径 $3 \mathrm{~mm}$ の穴を空けて，桁模型を差し込 
む形で橋脚上に設置した．S4，S5 のサイドブロックは 幅 $15 \mathrm{~mm}$ ，橋脚からの突出高さ $15 \mathrm{~mm}$ の直方体形状であ り，桁模型の両側に，桁模型との隙間が上下流側でそれ ぞれ $0.5 \mathrm{~mm}$ となるように設置した．S5 では，直径 $2 \mathrm{~mm}$ の真鍮棒を用いて橋析側に固定し，サイドブロックに直 径 3mm の穴を設けて設置した.

\section{（2） 実験方法}

実験は，橋脚試験体および橋析試験体を設置後，橋桁 試験体が移動するまで流量を徐々に増やしながら，以下 に示す項目を計測した．桁が移動した段階で実験を終了 し，また実験装置の最大流量を流しても移動しない場合 は，その段階で実験終了とした，下流端に設置した堰の 高さを変化させることにより，初期水深すなわち流速と 水深の関係を 2 種類について実験した．表-1に実験ケー スを示寸が，ここで初期水深は堰高に一致し，流量 0 に おける水深を意味している．ただし，計測は水面が橋桁 に接触しない程度に初期流量をあらかじめ流し，計測開 始後に流量を徐々に増やした。

水位，流速は，図-2に示寸地点で計測した，水位は， 計 5 点計測しており, 橋りょう模型中心より上流側 $1.0 \mathrm{~m}, 2.0 \mathrm{~m}, 4.0 \mathrm{~m}, 8.0 \mathrm{~m}$ の地点については容量式水位計 で，下流側 3.72m の地点については超音波水位計で計測
した。流速は電磁流速計により計測し，橋りょう模型中 心より上流側 $1.0 \mathrm{~m}, 2.0 \mathrm{~m}$ の地点の上層, 下層の 2 点で 計測した．計測高さは，V2，V4 の流速計については橋 脚中央の高さ，V1，V3 の流速計については橋林の中央 高さとした. ただし，V1，V3 については，流量が増加 し橋桁が水没するまでは気中となるため，水位が十分増 加するまでは水面下の高さとし, 水位が増加した時点で 鋁直方向に設定した高さまで上昇させて計測した．計測 のサンプリング周波数は $10 \mathrm{~Hz}$ である.

橋脚の上流側と下流側の側面には，小型の圧力計（直 径 $10 \mathrm{~mm}$ ）を，圧力分布が適切に計測できるよう配置し た．また橋脚行座には，上・下流それぞれのゴム支承ま たは鋼支承に小型ロードセルを設置し，椼座に作用する 支持力を計測した．なお，橋脚に作用寸る圧力の特性を 明確にするため，橋桁を置かず橋脚のみとした状態でも 計測を行った.

流れの作用状況及び桁の移動状況については，水槽上 方及び水槽側面に設置したビデオにより撮影した.

\section{3. 実験結果}

\section{(1) 桁模型の流出結果}

表-1に，橋桁試験体の流出状況をまとめる．表中の $H$,

表-1 PC 桁流出時の流体情報 (上段) ${ }^{* 1}$ と流体力 (下段) ${ }^{* 2}$

\begin{tabular}{|c|c|c|c|c|c|c|c|}
\hline & 橋脚高さ & 初期水深 & S1 & $\mathrm{S} 2$ & S3 & S4 & S5 \\
\hline \multirow{2}{*}{$\begin{array}{c}\text { G1 } \\
\text { 下路桁 }\end{array}$} & \multirow{2}{*}{$5 \mathrm{~m}$} & $1 \mathrm{~m}$ & 未流出 & $\begin{array}{c}H=9.8, V=4.6 \\
2670,-4506,-11570\end{array}$ & 未流出 & 未流出 & 未流出 \\
\hline & & $0 \mathrm{~m}$ & 未流出 & ずれ & 未流出 & 未流出 & 未流出 \\
\hline \multirow{2}{*}{$\begin{array}{c}\mathrm{G} 2 \\
\mathrm{~T} \text { 形桁 } \\
\text { 防音壁あり }\end{array}$} & \multirow{2}{*}{$5 \mathrm{~m}$} & $1 \mathrm{~m}$ & $\begin{array}{c}H=9.8, V=4.2 \\
4426,-2051,1308\end{array}$ & $\begin{array}{c}H=8.2, V=3.7 \\
3444,-1343,3651\end{array}$ & $\begin{array}{c}H=11.7, V=4.6 \\
5148,-2571,5714\end{array}$ & $\begin{array}{c}H=11.6, V=4.6 \\
5303,-2683,5382\end{array}$ & 未流出 \\
\hline & & $0 \mathrm{~m}$ & $\begin{array}{c}H=9.9, V=4.4 \\
4759,-2291,514\end{array}$ & $\begin{array}{c}H=8.1, V=3.7 \\
3434,-1336,3674\end{array}$ & $\begin{array}{c}H=11.7, V=4.5 \\
5027,-2485,5971\end{array}$ & $\begin{array}{c}H=11.7, V=4.4 \\
4906,-2397,6231\end{array}$ & 未流出 \\
\hline \multirow{4}{*}{$\begin{array}{c}\mathrm{G} 3 \\
\mathrm{~T} \text { 形桁 } \\
\text { 防音壁なし }\end{array}$} & \multirow{2}{*}{$10 \mathrm{~m}$} & $4.2 \mathrm{~m}$ & ずれ & $\begin{array}{c}H=12.7, V=3.3 \\
219,896,-783\end{array}$ & 未流出 & 未流出 & 未流出 \\
\hline & & $3.6 \mathrm{~m}$ & 未流出 & $\begin{array}{c}H=12.2, V=3.5 \\
348,738,-697\end{array}$ & 未流出 & 未流出 & 未流出 \\
\hline & \multirow{2}{*}{$5 \mathrm{~m}$} & $1 \mathrm{~m}$ & $\begin{array}{c}H=9.5, V=4.4 \\
2489,-493,2318\end{array}$ & $\begin{array}{c}H=8.2, V=3.9 \\
1862,174,2818\end{array}$ & $\begin{array}{c}H=11.7, V=5.4 \\
3652,-1732,1390\end{array}$ & ずれ & 未流出 \\
\hline & & $0 \mathrm{~m}$ & $\begin{array}{c}H=9.4, V=4.5 \\
2631,-645,2204\end{array}$ & $\begin{array}{c}H=8.5, V=4.2 \\
2180,-165,2564\end{array}$ & $\begin{array}{c}H=11.7, V=5.3 \\
3544,-1616,1476\end{array}$ & ずれ & 未流出 \\
\hline
\end{tabular}

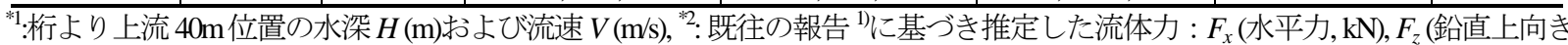
力, $\mathrm{kN}), M_{y}$ (橋軸回りのモーメント, $\left.\mathrm{kNm}\right)$ の順に示す.

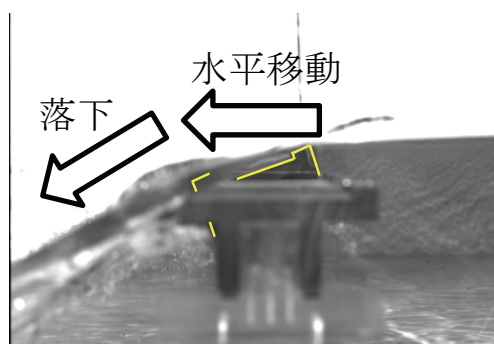

(a) G3P05S1

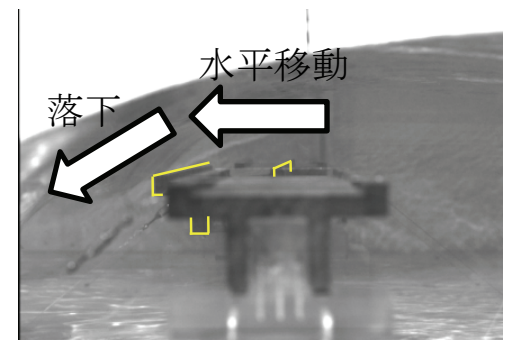

(b) G3P05S2

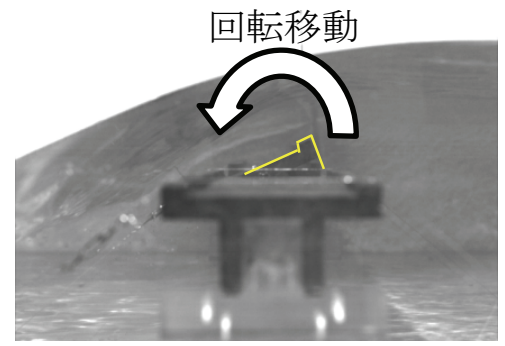

(c) G3P05S3

図6中央支間の橋桁試験体の流出状況(高速度カメラ撮影，図中の線は橋桁試験体形状を示す) 




(a)水位・流速
$\mathrm{V}(\mathrm{m} / \mathrm{s}) \mathrm{P}(\mathrm{kPa})$

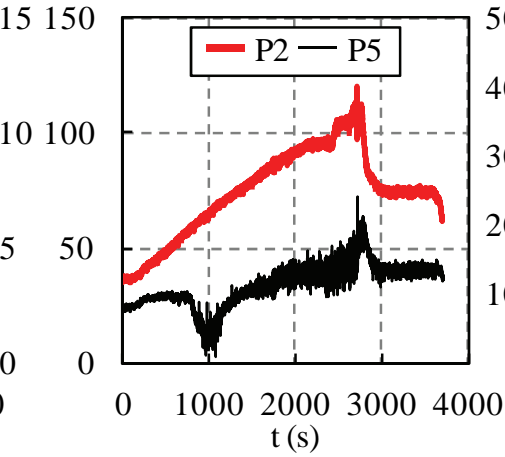

(b)橋脚側面圧力
$\mathrm{F}(\mathrm{kN})$

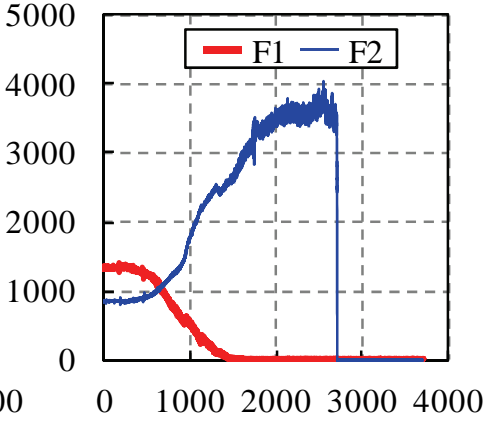

$\mathrm{t}(\mathrm{s})$

図-7 計測值の例（桁 $\mathrm{G} 3$ ，橋脚高さ $5 \mathrm{~m}$ ，支承 S3）

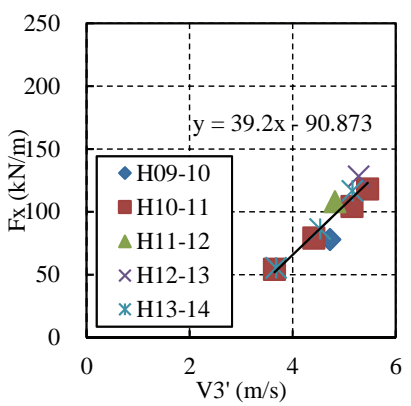

(a) G1

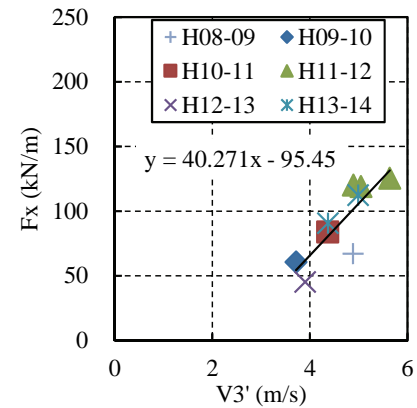

(b)G3
図-8 桁に作用寸る水平力 $F_{x}$ の推定（桁下空頭 $5 \mathrm{~m}$ )



(a)G1

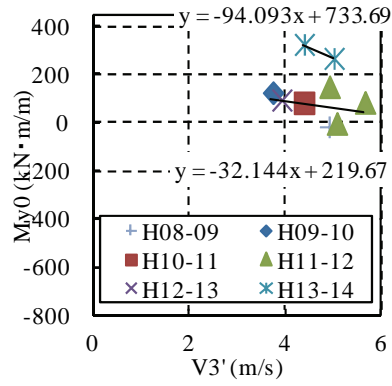

(b)G3
図-10 桁に作用するモーメント $M_{y 0}$ の推定（桁下空頭 5m)

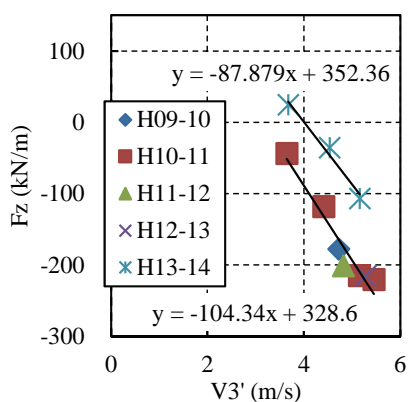

(a) $\mathrm{G} 1$



(b)G3

図-9＼cjkstart桁に作用寸る鉛直力 $F_{z}$ の推定（桁下空頭 $5 \mathrm{~m}$ )



図-11桁に作用する流体力と抵抗力

$V$ は，林が流出した瞬間の $1 \mathrm{~m}$ 上流における水位および 桁位置における流速を示している．表中の值は，実機に 換算して示した．なお，流出した瞬間は，後述するよう に下流側の桁座の支持力が抜けた瞬間としている。一部 のケースでは, 中央径間の桁が水平回転し，両側の桁と 接触して固定された(表-1 中の“ずれ”).この場合，桁の 流出した瞬間が不明なため水位，流速の值を示していな いが，条件としては流出に相当する流体力が働いていた ものと推定できる. 下段に示した数字は, 後述する, 既 往の成果 ${ }^{1)}$ に基づき水深と流速加算出した, 水平力, 鉛直上向き力，下流側下端（支承部）周りの回転モ一メ ントをそれぞれ示している.

図-6に橋りょう模型の流出状況を示す．支承 S1, S2 では, 桁が水平方向下流側に移動後, 桁座から落下して
流出した（図-6 (a)(b)）。S2 では全てのケースで桁が流 出したが，S1 では一部のケースで析の流出が生じなか った. これは，支承の摩擦係数の違いによるものと考え らえる。一方，移動制限装置が累加された S3，S4 では, 桁の水平移動が拘束されるため, 下流側支承を支点に回 転して下流側に流出した（図-6 (c)）。また，S3，S4 で は，同じケースで桁の流出が阻止されている．両者は， 水平方向の移動が拘束され，鉛直上向きには抵抗力が働 かないという同条件であり，ここでの桁の流下に対して は同様の機能を有することが分かる.S5 では栴の流出 は発生しなかった。

図-7 に，計測された水位 $H ，$ 流速 $V$ ，橋脚側面の圧力 $p$, 桁座の荷重 $F$ について時系列の例を示寸. 図-7 (a)よ り, 流量の増加に伴い水位・流速が増加し, 桁流出後水 


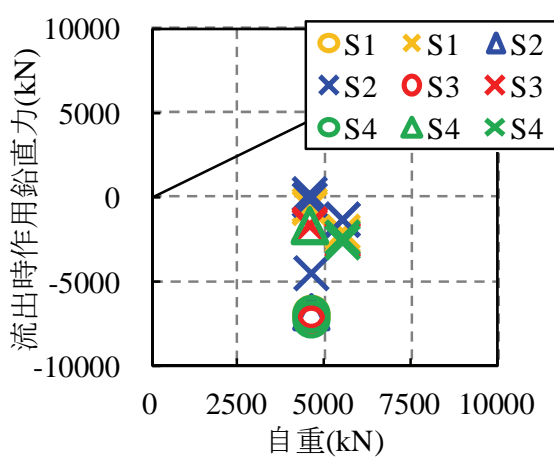

(a)鉛直方向

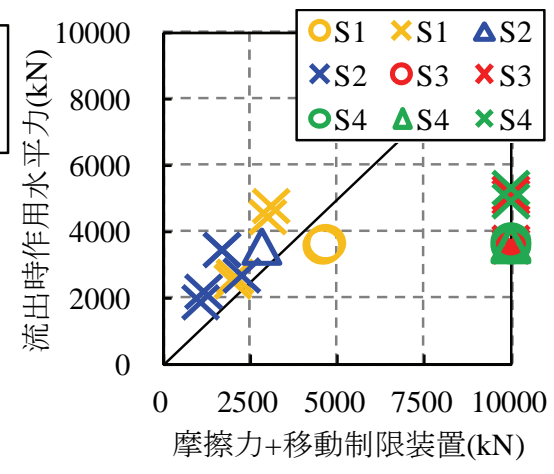

(b) 水平方向

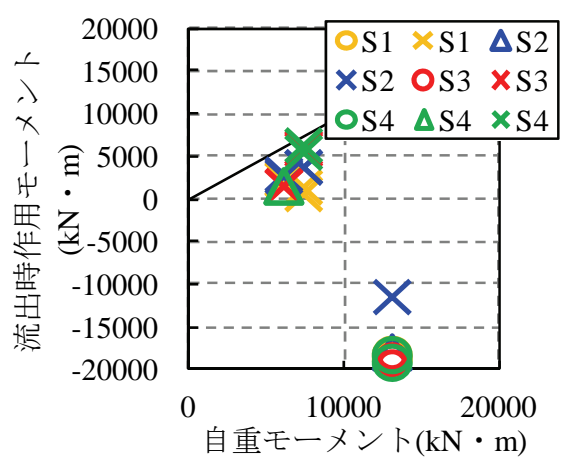

(c) 回転

図-12 作用力と抵抗力の関係（P5：橋脚高さ $5 \mathrm{~m}$ )



(a)鉛直方向

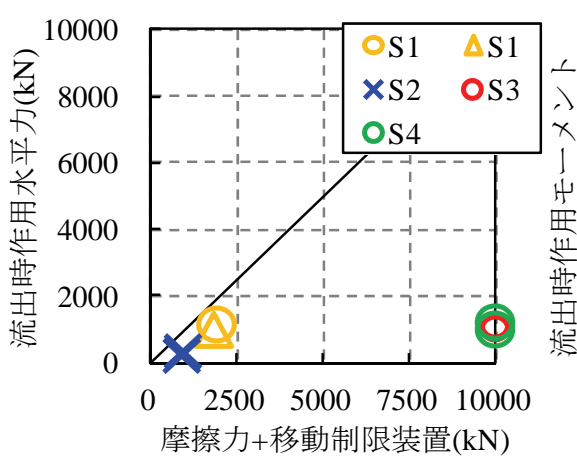

(b) 水平方向

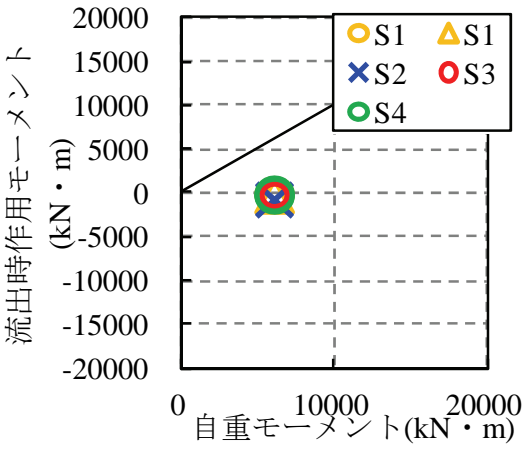

(c) 回転

図-13 作用力と抵抗力の関係（P10 : 橋脚高さ 10m)

位・流速が減少したことが分かる．図-7 (b)では，林の上 流側では堰上げにより水位が上昇するため，橋脚上流側 の圧力に比べて下流側の圧力が小さい. また，1000s 付 近で一旦下流側の圧力が小さくなるが，これは流量の増 加ととも桁が水没し，桁の下流側で射流が生じて水深が 小さくなったためと考えられる. 図-7 (c)の析座の支持力 では，上流側は流量の増加に伴い支持力がゼロまで徐々 に低下していることが分かる. 下流側の支持力は徐々に 上昇するが，流量が十分増加するとある一定の值となり， 流出時に 0 となっている. 上流側と下流側の合計值は, 流量の増加とともに増加しており, 下向きの揚力が生じ ていることが分かる.

\section{（2）試験体の流出時に作用した流体力の評価}

図-8〜10 に，既往の成果 ${ }^{1}$ における，流速と，本実験 之同断面形状の桁に作用寸る水平力 $F_{x}$, 鉛直力 $F_{z}$, 橋 軸まわりのモーメント $M_{y}$ の関係を示寸. 図中のプロッ 卜は，水深の異なる実験ケースの結果を示したものであ るが， $F_{z}$ および $M_{y}$ では栴の水没の有無により関係が大 きく異なる結果となった，ただし，実験の範囲では，水 深に関わらず概ね 1 つるいは 2 つ直線で近似可能で あった．桁下空頭（=橋脚高さ），桁断面形状および水 深ごとに設定した図-8～10 中の近似式を用いることで， 任意の水深および流速における枌に作用した流体力が推
定可能となる，桁が流出した際の水深，流速を用いて流 体力 $\left(F_{x}, F_{z}, M_{y 0}\right)$ を推定した結果を，表-1 の下段に 示す.

図-11 に，ここで考慮した桁に作用する流体力を示寸.

$$
\begin{aligned}
& F_{x}=F_{x d} \\
& F_{z}=F_{z b}+F_{z l} \\
& M_{y b}=l_{x} \times F_{z l}+l_{x}{ }^{1} \times F_{z b}+l_{z} \times F_{x d}
\end{aligned}
$$

ここで, $F_{x d}$ : 水平方向の流体力, $F_{b b}$ : 浮力, $F_{z l}$ : 揚力, $l_{x}$ : 揚力作用位置と支点の水平距離, $l_{x}^{\prime}$ : 浮力作用位置 と支点の水平距離, $l_{z}$ : 水平力作用位置と支点の鉛直距 離である.

\section{(3) 試験体の流出に関する限界值評価と検証}

林流出に対する抵抗力 $\left(R_{x}, R_{z}, R_{y 0}\right)$ は，式(4)〜(6)に より算出した (図-11参照).

$$
\begin{aligned}
R_{x} & =\mu\left(F_{z m}+F_{z b}+F_{z l}\right)+R_{s h} \\
& =\mu\left(F_{z m}+F_{z}\right)+R_{s h} \\
R_{z} & =F_{z m} \\
R_{y b} & =l_{x} \times F_{z m}
\end{aligned}
$$

ここで， $\mu$ : 支承における摩擦係数, $F_{z m}$ : 自重, $R_{s h}$ : 移 動制限装置のせん断耐力である。なお，自重と浮力の作 用水平位置は一致 $\left(l_{x}{ }^{\prime}\right)$ 寸るものとし, 标の中心とした.

図-12，13 は，流体力を縦軸，抵抗力を横軸に，両者 
の関係を示したものである. 図中の○は表-1 における未 流出したケース， $\triangle$ はずれのケース，×は流出したケー スをそれぞれ表している．なお，水平方向(図-12，13 (b) において移動制限装置を設置したケースは，図の右 端にプロットした。

鉛直方向（図-12，13 (a)）では，全てのケースで流体 力が抵抗力を下回っており, 浮上による移動ケースはな いことを示している. また，流出時には下向きの流体力 が作用していることが分かる. 水平方向(図-12，13 (b)) では，水平移動した移動制限装置の無い S1, S2 のケース で，概ね作用力と抵抗力が一致しており，流出しないケ 一スでは作用力が抵抗力に対して小さい值を示している. また，S1 と S2 を比較すると，相対的に S1 の方が抵抗


流出寸るには，S1 のゴム支承の方がより大きな流体力 が作用する必要があることが分かる．下流側支承回りの モーメント(図-12,13 (c))によると, 水平移動した S1, S2 のケースでは, 回転方向の流体力が相対的に小さく, 回転移動した移動制限装置のある S3, S4 では作用力と抵 抗力が概略一致寸る傾向にあることが分かる. ただし， 水平力に比較して流体力と作用力の関係が明確でない. 回転方向の流体力は図-10 から求めているが, 計測点数 が少なくばらつきも大きいため, 流体力の算定精度に課 題が残る. 今後流体力の算定モデルを構築して, 流体力 の算定精度を高める必要がある。回転移動しなかった S3, S4 のケースでは, 負の回転流体力が働いている。こ れは下路桁（G1）のケースであり，桁高が低いために 水平方向の流体力が小さいケースである. 図-10(a)によ れば，流速が大きくなるほど負の回転流体力が働いてい る. 桁高が低い場合には，正の回転流体力として作用す る水平力が小さいため，下向きの流体力による負の回転 力が卓越することが分かる.

以上のように, 抵抗力と作用力の関係から, 桁の流出
形態によって流出を判断する指標（水平方向あるいは回 転方向）が異なることを説明できることが分かった.

\section{4. まとめ}

津波により準定常状態の流れが作用する状況を対象に， 桁・橋脚・支承部形式の異なる鉄道コンクリート橋りょ うの流出について，1/40 スケールの縮小橋りょう模型を 用いた流体作用実験を行った。 その結果，一様流による 桁流出に対寸る抵抗力は, 下路桁, $\mathrm{T}$ 形枌高欄なし, $\mathrm{T}$ 形枌高欄女りの順に高く, また支承形式として移動制限 装置の有効性を確認した. 既往の成果に基づき算出した 流体力（水平方向 $F_{x}$, 鉛直方向 $F_{z}$, 回転方向 $M_{y 0}$ ) と, 支承の摩擦力，ストッパーのせん断力により算出される 抵抗力を比較すると, 流体力の $\left(F_{x}, F_{z}, M_{y 0}\right)$ いずれか が抵抗力を上回ることで流出することが判定され，さら に流出状況と一致することを確認した.

なお，本研究は国土交通省の鉄道技術開発費補助金 を受けて実施した。

\section{参考文献}

1) 渡辺 健, 河村佳英, 大野又稔, 岡本 大, 織田幸伸 : 一様 流作用下におけるコンクリート鉄道橋りょうに働く流体 力に関する研究, 土木学会論文集 B2(海岸工学), Vol.70, No.2, I_856-I_860, 2014.

2) 土木学会編: 津波による橋梁構造物に及ぼす波力の評価 に関寸る調査研究委員会報告書, コンクリートライブラ リー140, 2013.

3) プレストレストコンクリート技術協会: 東日本大震災 PC 構造物災害調査報告書, 2011.

4) 土木学会 : 超高強度繊維補強コンクリート設計・施工指 針(案),コンクリートライブラリー113, 2004.

(2015.3.18 受付)

\section{EXPERIMENTAL STUDY ON LIMIT VALUES FOR COLLAPSE OF PC GIRDERS BY UNIFORMED FLOW OF WATER}

\section{Ken WATANABE, Yuto OHNO and Yukinobu ODA}

Some bridges have been failed by Tsunami and river flood in Japan. This means that there was no verification of the bridges caused by Tsunami. The authors have conducted experiments and numerical analysis in order to understand the limit value for collapse of PC girders: that is affected by the cross-section shape of beam, supported condition, and the restriction equipments for seismic force. This paper focused on the railway bridges having large depth of beam compared with the road bridges. The paper concluded that the limit values for flow-out of girders can be calculated by considering the the friction at the support and shear-load capacity of the restriction equipments. 